\title{
Fouling analysis of membrane bioreactor treating antibiotic production wastewater at different hydraulic retention times
}

\author{
Dawei Yu ${ }^{1,2} \cdot$ Yutao Chen ${ }^{1,2} \cdot$ Yuansong Wei ${ }^{1,2,3}$ • Jianxing Wang ${ }^{1,2} \cdot$ Yawei Wang $^{1,2}$. \\ Kun $\mathrm{Li}^{1,2}$
}

Received: 30 June 2015 / Accepted: 3 November 2015 /Published online: 13 November 2015

(C) Springer-Verlag Berlin Heidelberg 2015

\begin{abstract}
Membrane fouling, including foulants and factors, was investigated during hydraulic retention time (HRT) optimization of a membrane bioreactor (MBR) that treated wastewater from the production of antibiotics. The results showed that HRT played an important role in membrane fouling. Trans-membrane pressure (TMP), membrane flux, and resistance were stable at $-6 \mathrm{kPa}, 76 \mathrm{~L} \mathrm{~m}^{-2} \mathrm{~h}^{-1} \mathrm{bar}^{-1}$, and $4.5 \times$ $10^{12} \mathrm{~m}^{-1}$ when HRT was at 60,48 , and $36 \mathrm{~h}$, respectively. Using Fourier transform infrared spectroscopy, foulants were identified as carbohydrates and proteins, which correlated with effluent organic matter and effluent chemical oxygen demand (COD) compounds. Therefore, membrane fouling trends would benefit from low supernatant COD $\left(378 \mathrm{mg} \mathrm{L}^{-1}\right)$ and a low membrane removal rate $(26 \%)$ at a HRT of $36 \mathrm{~h}$. Serious membrane fouling at 72 and $24 \mathrm{~h}$ was related to soluble microbial products and extracellular polymeric substances in mixed liquor, respectively. Based on the
\end{abstract}

Responsible editor: Angeles Blanco

Electronic supplementary material The online version of this article (doi:10.1007/s11356-015-5751-5) contains supplementary material, which is available to authorized users.

Yuansong Wei

yswei@rcees.ac.cn

1 State Key Joint Laboratory of Environmental Simulation and Pollution Control, Research Center for Eco-Environmental Sciences, Chinese Academy of Sciences, Beijing 100085, China

2 Department of Water Pollution Control Technology, Research Center for Eco-Environmental Sciences, Chinese Academy of Sciences, Beijing 100085, China

3 Beijing Key Laboratory of Industrial Wastewater Treatment and Reuse, Research Center for Eco-Environmental Sciences, Chinese Academy of Sciences, Beijing 100085, China
TMP decrease and flux recovery after physical and chemical cleaning, irremovable fouling aggravation was related to extracellular polymeric substances' increase and soluble microbial products' decrease. According to changes in the specific oxygen uptake rate (SOUR) and mixed liquor suspended solids (MLSSs) during HRT optimization in this study, antibiotic production wastewater largely inhibited MLSS growth, which only increased from 4.5 to $5.0 \mathrm{~g} \mathrm{~L}^{-1}$ when HRT was decreased from 72 to $24 \mathrm{~h}$, but did not limit sludge activity. The results of a principal component analysis highlighted both proteins and carbohydrates in extracellular polymeric substances as the primary foulants. Membrane fouling associated with the first principal component was positively related to extracellular polymeric substances and negatively related to soluble microbial products. Principal component 2 was primarily related to proteins in the influent. Additional membrane fouling factors included biomass characteristics, operational conditions, and feed characteristics.

Keywords Fouling $\cdot$ Foulant $\cdot$ HRT $\cdot$ Effluent organic matter . Extracellular polymeric substances $\cdot$ Soluble microbial product $\cdot$ Correlation analysis $\cdot$ Principal component analysis

\section{Introduction}

Pharmaceutical wastewater treatment challenges have become more apparent in the last decade due to the rapidly increasing scale of discharges and more stringent discharge standards in China. The discharged pharmaceutical wastewater increased from 360 to $540 \times 10^{6} \mathrm{~m}^{3}(150 \%)$ between 2003 and 2013 (National Bureau of Statistic China 2014), which corresponds to $2 \%$ of total industrial wastewater produced in China. Pharmaceutical production wastewater has attracted additional attention because of its broad health implications (Berendonk 
et al. 2015). Along with increasing environmental protection requirements, the pharmaceutical industry is listed as one of 10 key industries that should be subject to more stringent wastewater discharge standards, according to the Action Plan for Water Pollution Prevention and Control issued in April 2015 (State Council of China 2015). Therefore, there is considerable impetus to develop strategies for upgrading activated sludge systems in existing biological pharmaceutical wastewater treatment facilities.

One effective way to update existing conventional activated sludge (CAS) systems in pharmaceutical wastewater treatment is to use membrane bioreactors (MBRs). MBRs have demonstrated higher removal rates of chemical oxygen demand (COD) and pharmaceuticals than CAS, but fouling is still a critical challenge (Lin et al. 2012). Pharmaceutical wastewater contains $10 \sim 40$ types of recalcitrant chemical materials that are the result of the complex pharmaceutical production process (Ministry of Environmental Protection of the People's Republic of China 2009). The existing activated sludge system is often shocked by volatile wastewater quantities and quality because pharmaceutical wastewater is typically discharged in batches (Ministry of Environmental Protection of the People's Republic of China 2009). Treated wastewater often contains a significant amount of recalcitrant pollutants because conventional activated sludge systems lack the capacity to remove them (Xing and Sun 2009). With prolonged solid retention time (SRT) achieved in a compacted reactor, MBR is now seen as a cost-effective method to remove recalcitrant organics (Hai et al. 2010). MBR is an attractive choice because stringent discharge standards can be satisfied within a limited footprint (Cheng 2012). Recalcitrant pollutants can be retained and removed by MBR (Sundararaman and Saravanane 2010; Xing and Sun 2009). When SRT is long enough, the retained recalcitrant organics may be biodegraded by the biomass within the limits of the substrates (Hai et al. 2010; Raj et al. 2013). Lin summarized the performance of MBR in treating pharmaceutical wastewater, highlighting the removal of pharmaceutical pollutants (Lin et al. 2012). Furthermore, downstream treatments can benefit from the higher organic removal rate provided by the MBR. Our previous studies have shown that a combined MBRnanofiltration (NF) process with recycling NF concentrate not only had high-quality permeate to meet the wastewater reuse requirement but also achieved a high water yield of 92 $\pm 5.6 \%$ (Wang et al. 2014b). MBR could biodegrade proteins, polysaccharides, and humic-like substances which are otherwise retained and recycled by the NF membrane without significant changes in the microbial community (Wang et al. 2014a, b, 2015).

A common operational counter measure for volatile and recalcitrant organic pollutants involves decreasing the organic loading rate by prolonging hydraulic retention time (HRT) (Sipma et al. 2010; Sundararaman and Saravanane 2010); however, a definite connection between HRT adjustment and membrane fouling trends is still missing in the treatment of pharmaceutical wastewater using a MBR. Tay investigated the effect of HRT on system performance in a submerged MBR treating simulated high-strength wastewater, and cues of the potential solution for the membrane fouling were studied during optimization of HRT from 6 days to $12 \mathrm{~h}$ (Tay et al. 2003). Zhou investigated the effects of MBR's operational parameters on membrane fouling in a submerged MBR designed to treat synthetic coke wastewater, and an optimum operation strategy to minimize membrane fouling required a HRT of $12 \mathrm{~h}$ (Zhou et al. 2009).

Therefore, the object of this paper was to further understand the relationship between HRT and membrane fouling in pharmaceutical production wastewater treatment using a MBR. This objective was achieved by investigating foulants in mixed liquor and MBR effluent, respectively. Meanwhile, an advanced statistical analysis was used to further analyze the relationship between membrane fouling and antibiotic production wastewater, biomass, and operational conditions.

\section{Materials and methods}

\section{MBR configurations}

A submerged MBR was used in this study (Table 1). A flat sheet membrane (PVDF, SINAP Ltd., Shanghai) was used as a solid and liquid separation and submerged in an aeration tank at $100 \mathrm{~L}$ of working volume. Permeate from the MBR membrane was intermittently obtained by using a peristaltic pump (BT600, Longer Pump Ltd., China). The membrane was chemically cleaned $(0.5 \% \mathrm{NaOCl})$ every 2 weeks. Antibiotic production wastewater was pumped automatically from a storage tank into the bioreactor using a feeding pump (BT300, Longer Pump Ltd., China).

\section{Pharmaceutical wastewater}

The feed wastewater was the effluent of an anaerobic digestion process from a wastewater treatment station in a pharmaceutical company producing spiramycin in Wuxi (China). The characteristics of this effluent are listed in Table 1.

\section{MBR operational conditions}

The MBR system was used to simulate upgrades to an existing activated sludge system in the wastewater treatment facilities $\left(500 \mathrm{~m}^{3}\right.$ day $\left.^{-1}\right)$ of the Wuxi 2nd Pharmaceutical Company. The initial operational conditions were the same as those for the existing activated sludge system (Online Resource 1). Extra alkalinity for nitrification was supplied in the form of $\mathrm{Na}_{2} \mathrm{CO}_{3}$ instead of $\mathrm{CaO}$ in situ. One-hundred liters of 
Table 1 Reactor configurations, operation conditions, and feed pharmaceutical wastewater characteristics in MBR at different HRTs

\begin{tabular}{|c|c|c|c|c|c|}
\hline Time (days) & $1 \sim 14$ & $15 \sim 28$ & $29 \sim 42$ & $43 \sim 56$ & (57) $71 \sim 84$ \\
\hline \multicolumn{6}{|l|}{ Configurations } \\
\hline Volume of bioreactor (L) & \multicolumn{5}{|l|}{$100 \mathrm{~L}$} \\
\hline Type of aeration tank & \multicolumn{5}{|c|}{ Continuous stirred-tank reactor } \\
\hline Membrane module & \multicolumn{5}{|c|}{ Flat sheet, PVDF, pore size $0.1 \mu \mathrm{m}$, membrane area $4 \times 0.055=0.22 \mathrm{~m}^{2}$} \\
\hline \multicolumn{6}{|l|}{ Operation conditions } \\
\hline HRT (h) & 72 & 60 & 48 & 36 & 24 \\
\hline $\mathrm{T}\left({ }^{\circ} \mathrm{C}\right)$ & $24.8 \pm 1.6$ & $27.3 \pm 0.7$ & $28.0 \pm 1.3$ & $29.7 \pm 0.5$ & $28.1 \pm 1.3$ \\
\hline $\mathrm{pH}$ & $6.79 \pm 0.14$ & $6.54 \pm 0.27$ & $6.41 \pm 0.27$ & $6.56 \pm 0.20$ & $6.25 \pm 0.90$ \\
\hline $\mathrm{DO}\left(\mathrm{mg} \mathrm{L}^{-1}\right)$ & $4.52 \pm 0.29$ & $3.67 \pm 0.65$ & $3.60 \pm 0.80$ & $3.61 \pm 1.00$ & $4.35 \pm 2.11$ \\
\hline SRT (days) & \multicolumn{5}{|l|}{70} \\
\hline $\operatorname{MLSS}\left(\mathrm{g} \mathrm{L}^{-1}\right)$ & $4.47 \pm 0.82$ & $3.74 \pm 0.24$ & $3.96 \pm 0.07$ & $3.82 \pm 0.01$ & $4.95 \pm 0.77$ \\
\hline $\operatorname{MLVSS}\left(\mathrm{g} \mathrm{L}^{-1}\right)$ & $3.33 \pm 0.68$ & $2.76 \pm 0.14$ & $2.76 \pm 0.10$ & $2.91 \pm 0.20$ & $3.88 \pm 0.63$ \\
\hline MLVSS/MLSS & $0.74 \pm 0.02$ & $0.73 \pm 0.01$ & $0.69 \pm 0.01$ & $0.76 \pm 0.05$ & $0.78 \pm 0.01$ \\
\hline Organic loading rate $\left(\mathrm{kg}_{\mathrm{COD}} \mathrm{kg}_{\mathrm{VSS}}{ }^{-1} \mathrm{day}^{-1}\right)$ & $0.08 \pm 0.04$ & $0.13 \pm 0.02$ & $0.18 \pm 0.01$ & $0.19 \pm 0.01$ & $0.38 \pm 0.04$ \\
\hline $\mathrm{NH}_{4}{ }^{+}-\mathrm{N}$ loading rate $\left(\mathrm{g}_{\mathrm{NH} 4 \pm \mathrm{N}} \mathrm{kg}_{\mathrm{VSS}}{ }^{-1} \mathrm{day}^{-1}\right)$ & $0.016 \pm 0.00$ & $0.024 \pm 0.00$ & $0.035 \pm 0.00$ & $0.047 \pm 0.00$ & $0.094 \pm 0.02$ \\
\hline \multicolumn{6}{|l|}{ Feed pharmaceutical wastewater } \\
\hline $\mathrm{COD}\left(\mathrm{mg} \mathrm{L}^{-1}\right)$ & $800 \sim 2000$ & \multicolumn{3}{|c|}{ Spiramycin $\left(\mathrm{mg} \mathrm{L}^{-1}\right)$} & $10 \sim 20$ \\
\hline $\mathrm{NH}_{4}{ }^{+}-\mathrm{N}\left(\mathrm{mg} \mathrm{L}^{-1}\right)$ & $150 \sim 300$ & \multicolumn{3}{|c|}{$\mathrm{Cl}^{-}\left(\mathrm{mg} \mathrm{L}^{-1}\right)$} & $1600 \sim 2000$ \\
\hline $\mathrm{TN}\left(\mathrm{mg} \mathrm{L}^{-1}\right)$ & $280 \sim 400$ & \multicolumn{3}{|c|}{$\mathrm{Ca}^{2+}\left(\mathrm{mg} \mathrm{L}^{-1}\right)$} & $200 \sim 300$ \\
\hline $\mathrm{TP}\left(\mathrm{mg} \mathrm{L}^{-1}\right)$ & $6 \sim 20$ & \multicolumn{3}{|c|}{$\mathrm{Na}^{+}\left(\mathrm{mg} \mathrm{L}^{-1}\right)$} & $700 \sim 1200$ \\
\hline $\mathrm{SS}\left(\mathrm{mg} \mathrm{L}^{-1}\right)$ & $700 \sim 1000$ & \multicolumn{4}{|c|}{-} \\
\hline
\end{tabular}

activated sludge at $4.47 \pm 0.82 \mathrm{~g} \mathrm{~L}^{-1}$ mixed liquor suspended solid (MLSS) from the existing activated sludge system of Wuxi 2nd Pharmaceutical Company was inoculated at a sludge loading rate of $0.08 \pm 0.04 \mathrm{~kg}_{\mathrm{COD}} \mathrm{kg}_{\mathrm{VSS}}{ }^{-1} \mathrm{day}^{-1}$. The feeding pump was controlled by a level sensor and an electric relay (JYB-714, Xinling Ltd., China). The membrane filtration was intermittently sucked in the interval mode of 6 min on and 2 min off. The membrane was operated in constant flux mode. The membrane's critical flux was $12.24 \mathrm{~L} \mathrm{~m}^{-2} \mathrm{~h}^{-1}$, and a subcritical flux value of $6.5 \mathrm{~L} \mathrm{~m}^{-2} \mathrm{~h}$ was used in this work (Cheng et al. 2012). The trans-membrane pressure (TMP) of the MBR was kept constant below $-25 \mathrm{kPa}$ by a pressure sensor (HSCH6/C-HRT, Shi-he Ltd., Beijing). If the pressure was too high, intensive aeration was performed firstly, and then, chemical cleaning was applied. As no excess sludge was discharged in this MBR operation except for during sludge sampling, the MLSS barely increased at any stage after the initial growth, which was similar to results found in a previous work (Sun et al. 2006).

The MBR had been running for 76 days before this study began. The 205 days of the MBR's operation during this study were divided into two periods (Online Resource 1). Period 1 (0 121 days) operated steadily for 84 days at $72 \mathrm{~h}$ following the MBR's start-up in the first 37 days. Period 2 (122 207 days) operated for 85 days to allow for HRT adjustments, in which HRT was gradually decreased following a stepwise method. The HRT was reduced by $12 \mathrm{~h}$ once every 2 weeks; this was considered a steady state for over three HRTs (Viero and Sant'Anna 2008). Five stages were carried out over those 85 days (Table 1). No sludge was discharged except for sludge sampling, resulting in prolonged SRT over 70 days. In all HRT adjustment stages, effluent COD and MLSS achieved a stable state before the next adjustment.

\section{Membrane foulants}

Extracellular polymeric substances (EPSs) and soluble microbial products (SMPs) were extracted using a thermal treatment method (Chang and Lee 1998) twice a week approximately. The mixed liquor was firstly separated as supernatant and sludge using a centrifuge (4000 rpm, $30 \mathrm{~min}$ ). The first supernatant was a SMP solution, while the remaining sludge was resuspended with saline water $(0.9 \% \mathrm{NaCl}$ solution) to its original volume. The re-suspended liquor was then subjected to a heat treatment $\left(100{ }^{\circ} \mathrm{C}, 1 \mathrm{~h}\right)$ and centrifuged $(4000 \mathrm{rpm}$, $30 \mathrm{~min}$ ) again. The second supernatant was an EPS solution. Both supernatants were filtered through a $0.45-\mu \mathrm{m}$ cellulose acetate membrane before proteins and carbohydrates were quantified (Malamis and Andreadakis 2009). Proteins and carbohydrates of both supernatants were determined using Lowry (Lowry et al. 1951) and Dubois's methods (DuBois et al. 1956). The reference standard was the bovine serum albumin and D- 
glucose (Sinopharm Chemical Reagent Co., Ltd). Effluent organic matter (EfOM) was analyzed by following the same procedure as outlined for proteins and carbohydrates. To compare these data with the measured COD effluent according to Jang's research (Janga et al. 2007), the following equation was used:

$$
\begin{aligned}
\text { Calculated COD }= & 1.25 \mathrm{~g}_{\mathrm{COD}} \mathrm{g}^{-1} \times \text { Carbohydrate } \\
& +1.80 \mathrm{~g}_{\mathrm{COD}} \mathrm{g}^{-1} \times \text { Protein }
\end{aligned}
$$

Membrane foulants were sampled for Fourier transform infrared spectroscopy (FTIR) analysis at the end of each HRT stage. Membrane foulants were first scratched from the membrane using a plastic board and then flushed with ultrapure water; next, they were dissolved into $500 \mathrm{~mL}$ deionized water using a magnetic stirrer. A $200 \mathrm{~mL}$ sample was dried at $70{ }^{\circ} \mathrm{C}$ for $48 \mathrm{~h}$ and then smashed as powder. The powder was mixed and compacted with $\mathrm{KBr}$ at a mass ratio of 2:100 for FTIR analysis by a Fourier transform infrared spectroscope (Nicolet 750, American).

\section{Analysis}

Samples of influent, mixed liquor and effluent were taken for analysis twice a week. The mixed liquor was firstly centrifuged at $8000 \mathrm{rpm}$ for $10 \mathrm{~min}$ at $4{ }^{\circ} \mathrm{C}$ using a TGL-16 M (Xiangyi, China), and then, it was filtered through a 0.45 - $\mu$ m membrane (Membrana, Germany) to obtain the supernatant. The COD concentrations were determined following the standard method (Water and Wastewater Monitoring Method Editorial Committee 2002) via a spectrophotometer (DR2800, HACH Inc., USA). $\mathrm{NH}_{4}{ }^{+}-\mathrm{N}, \mathrm{TN}$, and TP were also determined following the standard method (Water and Wastewater Monitoring Method Editorial Committee 2002) using $\mathrm{SAN}^{++}$(Skalar/SmartChem, USA). Total organic carbon (TOC) was measured with a LiquiTOC (Elementar, Germany). $\mathrm{Ca}^{2+}$ and $\mathrm{Mg}^{2+}$ were measured using an inductively coupled plasma with optical emission spectroscopy (Optima 2000DV, PE, USA). $\mathrm{Cl}^{-}$was measured by an ion chromatograph (ICS-1000, Waters, USA). The concentrations of total suspended solids (TSSs) and volatile suspended solids (VSSs) were determined at $104{ }^{\circ} \mathrm{C}(4 \mathrm{~h})$ and $600{ }^{\circ} \mathrm{C}(2 \mathrm{~h})$, respectively. Specific oxygen uptake rate (SOUR) values were tested using a Winkler bottle and the oxygen consumption method (Jubany et al. 2005; Ng et al. 2006). Particle size distribution was analyzed using size exclusion chromatography (Malvern Mastersizer 2000, Malvern Instruments Ltd., England).

Statistical analyses, including a principal component analysis (PCA) and a Pearson's correlation analysis, were carried out using SPSS software (20.0, SPSS Inc., USA). The PCA is an advanced regression technique and a dimension reduction statistical method generally used to arrange a large set of variables into several major components (Naessens et al. 2012).
PCA was carried out in this study to identify principal components (PCs) that would explain and illustrate the data in terms of the following four classic categories (Meng et al. 2009; Zuriaga-Agustí et al. 2014): feed characteristics (e.g., protein, carbohydrate, TOC, and ammonia), biomass characteristics (e.g., viscosity, specific viscosity, capillary suction time (CST), TOC, EPS, and SMP, including proteins and carbohydrates), membrane characteristics, and operational conditions (e.g., organic loading rate (OLR), mixed liquor volatile suspended solid (MLVSS), SOUR, $f$, resistance, and effluent). Our previous studies have shown that membrane characteristics are important in the membrane fouling of MBR treating pharmaceutical wastewater (Cheng et al. 2012), so these characteristics were not included in this investigation. In this study, three classic categories, including feed wastewater, biomass, and operational parameters, were used in the PCA to analyze the factors affecting membrane fouling.

\section{Results and discussion}

\section{Membrane fouling}

TMP and flux values throughout the study are shown in Fig. 1a. TMP was stable when HRT ranged from 36 to $64 \mathrm{~h}$ and fluctuated beyond that range. A sudden increase in TMP was observed when HRT was at $72 \mathrm{~h}$. Five days after the first increase in TMP, 24-h aeration without effluent operation was performed to physically clean the membrane; however, while TMP decreased for 1 day, it rose above $-45 \mathrm{kPa}$ on the seventh day again. Then, a cleaning in place (CIP) chemical cleaning and another aeration without effluent operation were executed, suggesting that high fouling rates occurred with the removable and irremovable foulants at a 72-h HRT. Then, the TMP fluctuated less at 60-h HRT. Chemical cleaning and intensive aeration were performed only twice, once on days 20 and 23 , respectively. The TMP was stable around $-6.3 \mathrm{kPa}$ when HRT was at 36 and $48 \mathrm{~h}$, which indicated that the fouling occurred slowly and was reversible in these two stages. However, the TMP linearly increased despite intensive aeration performed when HRT was at $24 \mathrm{~h}$. These results clearly show that membrane fouling under $-15 \mathrm{kPa}$ in the early stages of treatment could be recovered by non-effluent aeration but could not be recovered from day 66 to day 73 . Operating flux decreased on day 7 and day 21 . The operating flux was stable but slightly lower than the subcritical flux when HRT was at $48 \mathrm{~h}$; however, this value fluctuated when HRT was $24 \mathrm{~h}$.

Figure $1 \mathrm{~b}$ shows permeability flux and membrane resistance at these five HRT stages. Permeability flux could recover by non-effluent aeration and remain stable during the stages of HRT at 60,48 , and $36 \mathrm{~h}$; however, these values dropped rapidly and failed to recover during the stage of HRT at $24 \mathrm{~h}$. The CIP chemical cleaning recovered permeability flux 

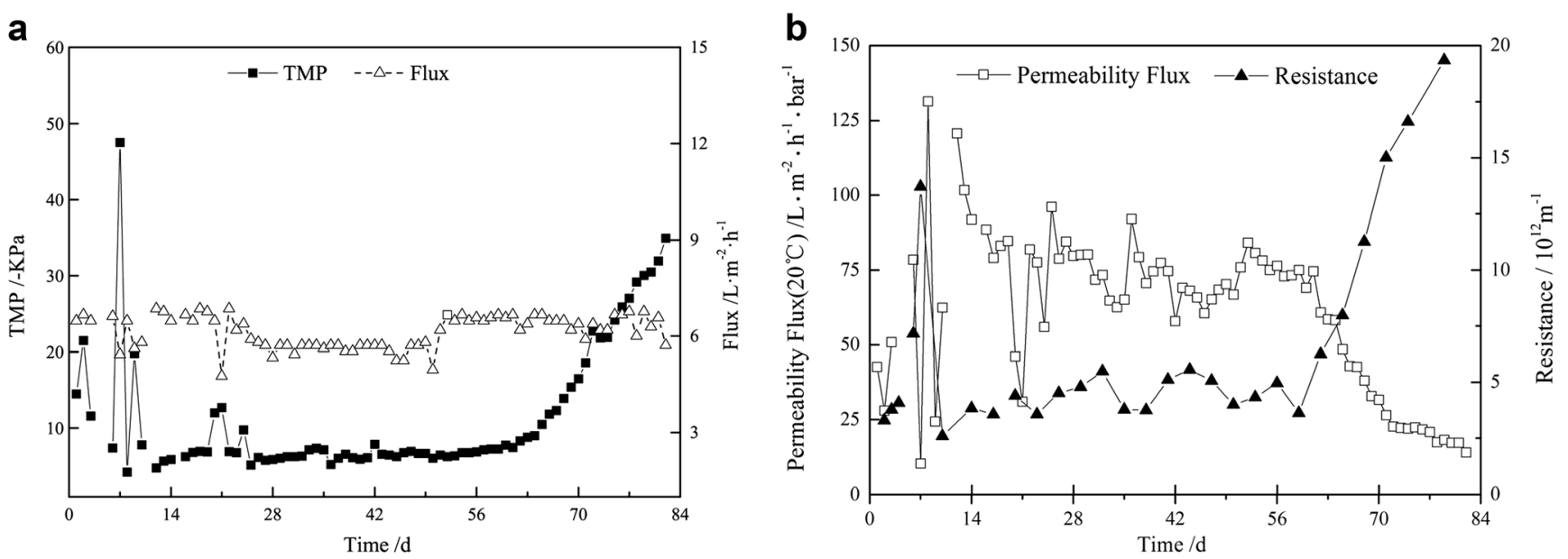

Fig. 1 Effects of HRT on membrane fouling processes (a TMP and flux and b permeability flux and resistance)

greatly, except when HRT was at $72 \mathrm{~h}$. Irremovable fouling trends became more serious as HRT decreased to $24 \mathrm{~h}$.

Based on the TMP decrease and flux recovery after the physical and chemical cleaning, fouling was determined to occur in the following three ways: removable fouling, irremovable fouling, and irreversible fouling between HRT adjustments. If the TMP decrease and flux recovery occurred as the result of a physical cleaning, it was classified as removable fouling. Irremovable fouling occurred when foulant remained after a physical cleaning but could be reversed by chemical cleaning. Irreversible fouling occurred when a foulant residue remained even after chemical cleaning (Meng et al. 2009). In the first two HRT stages, fouling was primarily removable and became irremovable after a few days. When HRT was decreased to 48 and $36 \mathrm{~h}$, both removable and irremovable fouling were mitigated. The likelihood of irremovable fouling occurring was mitigated when the HRT was decreased from 72 to $36 \mathrm{~h}$. A further decrease in HRT led to irremovable fouling increasing rapidly. Its TMP rapidly increased, and permeability flux sharply decreased when the HRT was decreased to $24 \mathrm{~h}$. An optimized HRT that took into account membrane fouling mitigation was therefore set from 48 to $36 \mathrm{~h}$ to treat wastewater from antibiotics production using a MBR in this study. Obviously, HRT plays an important role in the fouling trends of MBR.

The HRT range of fouling changes is broad for pharmaceutical wastewater when compared to MBRs used to treat municipal wastewater, but the relative value was narrow. Meng reported that fouling trends greatly changed when HRT decreased from $10-12$ to $6-8 \mathrm{~h}$, but further decreasing the HRT to $4-5 \mathrm{~h}$ resulted in limited changes to fouling trends of municipal wastewater. The effects of the OLR on membrane fouling were emphasized in municipal wastewater treated by MBR. A high OLR (1.5 g TOC L ${ }^{-1}$ day $^{-1}$ ) revealed a sudden increase in the TMP and a decrease in flux after 40 days in municipal wastewater treatment by MBR, but a OLR of $0.38 \pm$ $0.04 \mathrm{~kg}_{\mathrm{COD}} \mathrm{kg}_{\mathrm{Vss}}{ }^{-1} \mathrm{day}^{-1}$ resulted in similar serious fouling trends (Meng et al. 2007; Nagaoka et al. 1998; Shariati et al.
2011). In this study, the OLR remained stable when HRT was at 60,48 , and $36 \mathrm{~h}$, respectively, and sharply doubled when HRT was set to $24 \mathrm{~h}$. Correspondingly, membrane fouling showed similar trends. The data obtained from this investigation, together with previous works in the literature related to municipal wastewater treatment, indicate that HRT is a very significant operating parameter that affects membrane fouling and performance in municipal and industrial MBR systems.

\section{Membrane foulants}

\section{Determining membrane foulants using FTIR}

To identify organic compounds that contributed to irreversible membrane fouling, an FTIR analysis of membrane foulants scratched from the surface of the membrane was carried out (Fig. 2). There were many characteristic peaks present within the detection range of 4000 and $400 \mathrm{~cm}^{-1}$. The large peak recorded approximately $3427 \mathrm{~cm}^{-1}$ is related to the hydroxyl $(\mathrm{O}-\mathrm{H})$ band, and the peak at $2926 \mathrm{~cm}^{-1}$ is attributed to vibration of the hydrocarbon subsidiary $(\mathrm{C}-\mathrm{H})$ band (Croue et al. 2003). There are two characteristic protein peaks at 1655 and $1554 \mathrm{~cm}^{-1}$, which are related to the amide I (carbonyl) and amide II (N-H) bands (Saha et al. 2007), respectively. These peaks indicated that foulants in this study contained proteins. The peak at $1384 \mathrm{~cm}^{-1}$ is linked to the C-O band. Polysaccharides typically have intense C-O stretching bands at $1043 \mathrm{~cm}^{-1}$ (Croue et al. 2003). These results indicate that the gel layer also contained polysaccharides (Pendashteh et al. 2011). FTIR results suggested that the membrane foulants in this study contained proteins and carbohydrates.

\section{Membrane foulants quantified as bound EPS, bound SMP, and EfOM}

EfOM is a complex mixture of SMP secreted by microorganisms during biological treatment processes and synthetic 

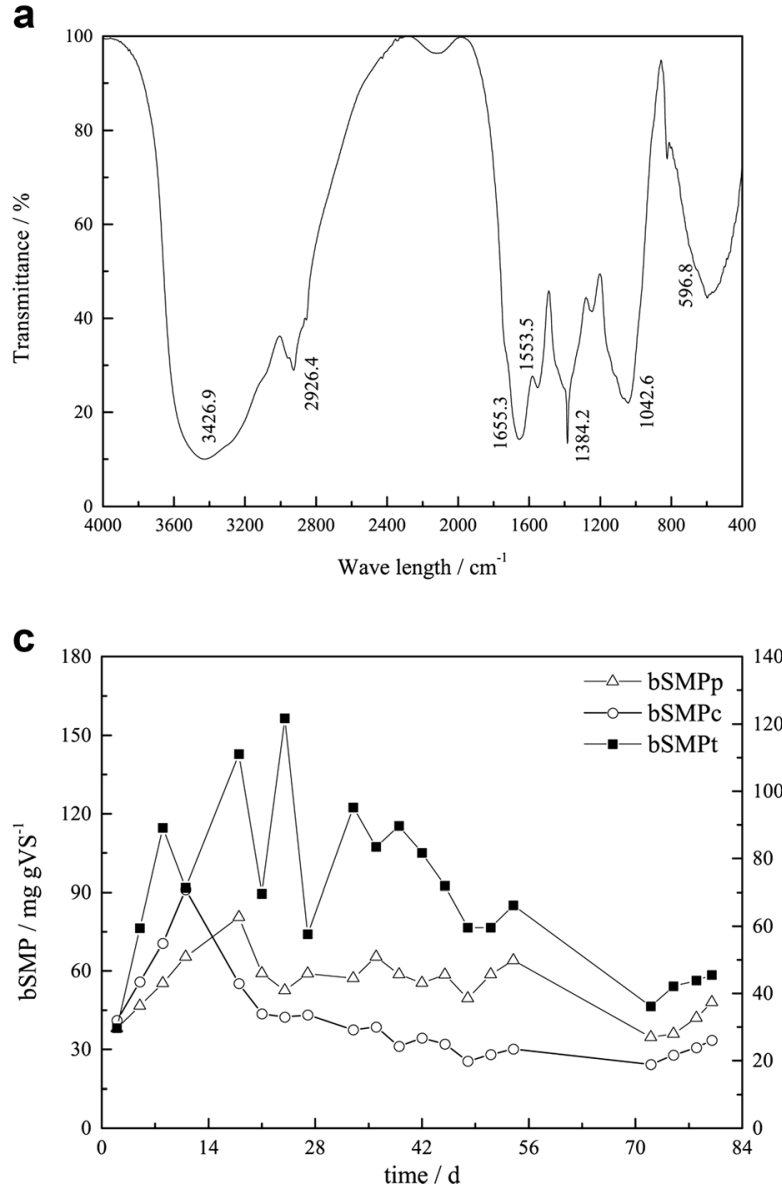

b

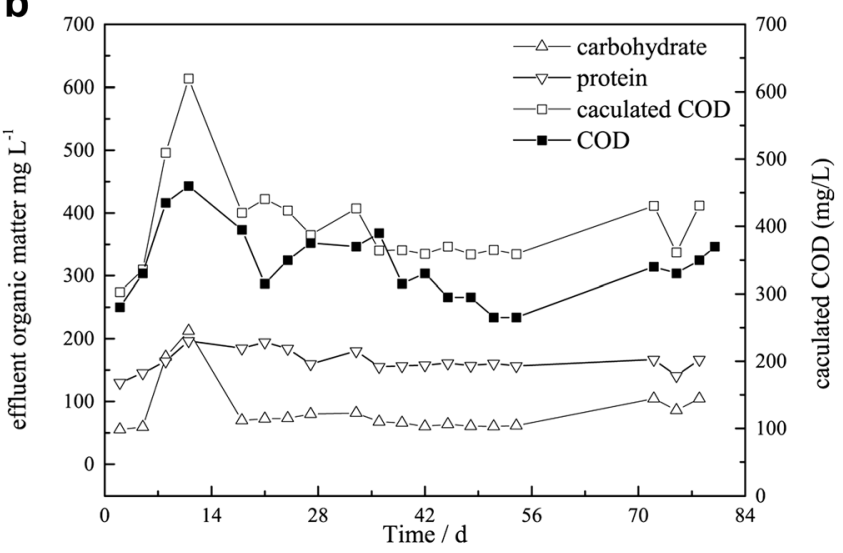

d

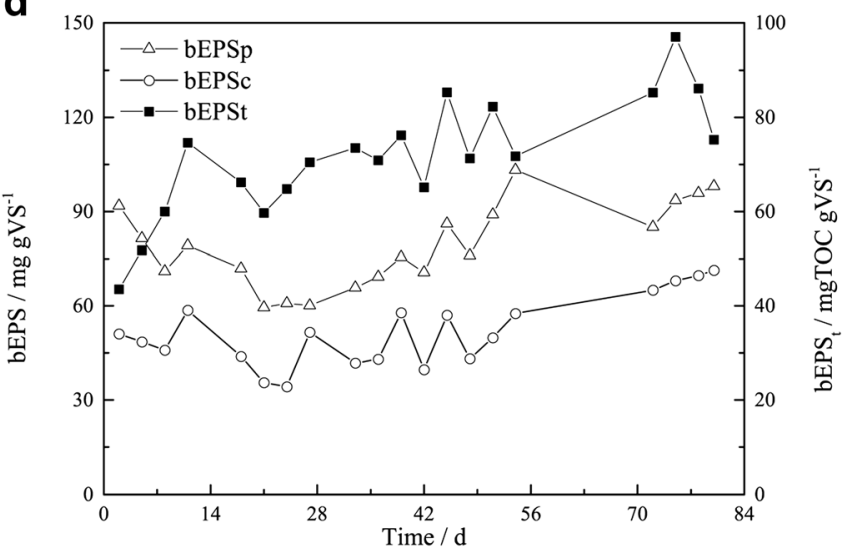

Fig. 2 Effects of different HRTs on foulant (a FTIR analyses of foulant, $\mathbf{b}$ protein and carbohydrate in permeate, $\mathbf{c} b S M P$ in mixed liquor, and $\mathbf{d} b E P S$ in mixed liquor)

organics due to human activities, which should be highlighted in pharmaceutical wastewater treatment and natural organic matter (NOM) presence in tap water (Shon et al. 2006). As shown in Fig. 2b, EfOM (particularly carbohydrates) suddenly increased to $213 \mathrm{mg} \mathrm{L}^{-1}$, over twice the normal levels at the 72-h HRT stage. These values fluctuated less when the HRT equalled $60 \mathrm{~h}$ and were relatively stable when HRT equalled 48 and 36 h. EfOM (Fig. 2b) results showed concordant trends with TMP (Fig. 1a), which fluctuated at the beginning, stable in the middle stage, and rose near the end. In addition, calculated COD effluent exhibited similar patterns and approximate values with effluent COD. These results showed that proteins and carbohydrates were not only the major foulant components but were also the major compounds of the permeate COD.

As shown in Fig. 2c, d, bound EPS (bEPS), bound SMP (bSMP), and their compounds within the mixed liquor were quantified as proteins and carbohydrates according to the FTIR results. MLVSS remained stable throughout this study (Table 1). As HRT decreased, bSMP and bEPS values decreased and increased, respectively (Fig. 1b). In the first HRT stage $(H R T=72 \mathrm{~h}), \mathrm{bSMP}_{\mathrm{t}}$ suddenly rose to
$118 \mathrm{mg} \mathrm{gVS}^{-1}$ when permeability flux dropped (Fig. 1b). Another two peaks were observed in both bSMP $_{t}$ and permeability flux at a HRT of $60 \mathrm{~h}$. Both $\mathrm{bSMP}_{\mathrm{t}}$ and permeability flux were stable at 48 and $36 \mathrm{~h}$; however, bSMP $_{\mathrm{t}}$ and permeability flux trends diverged when HRT equalled $24 \mathrm{~h}$. The analysis, which was based on physical and chemical cleaning, showed that removable fouling and bSMP followed similar trends. The decreasing trends in permeability flux were associated with increasing trends in bEPS $\left(149 \mathrm{mg} \mathrm{gVS}^{-1}\right)$ when HRT equalled $24 \mathrm{~h}$. bEPS (Fig. 1d) fluctuated initially and then rose, similar to irremovable fouling trends identified in this investigation. To be more specific, bEPS $_{\mathfrak{p}}(0.826, p<0.01)$ and $\mathrm{bEPS}_{\mathrm{c}}(0.797, p<0.05)$ were significantly related to fouling rate. According to the fouling and foulant results in this study, it can further be inferred that the dominant foulants transitioned from SMP to bEPS as HRT decreased from 72 to $24 \mathrm{~h}$ in the MBR treating pharmaceutical wastewater. Initial foulants were dominated by bSMP, which was secreted by microorganisms during prolonged HRT (72 h) and inhibited by man-made chemical agents. Under an optimized HRT (48 and $36 \mathrm{~h}$ ), both bSMP and bEPS were limited. Final fouling was dominated by bEPS, which could not be removed using 
man-made chemical agents during the shortened HRT. However, further investigation is still needed to provide more direct evidence related to this assumption.

\section{Pollutants removed by membrane and biomass}

When mixed liquor permeates a membrane, total COD is separated into two parts by the membrane. The first part was retained by the cake layer and the membrane as foulant (Fig. 3a). The other parts permeate the membrane as EfOM (Fig. 2d). Both the supernatant- and membrane-removed COD concentrations were lowest at $36 \mathrm{~h}$ (Fig. 3a, b), which was consistent with fouling trends (Fig. 1). This also indicates that the highest biomass removal rate occurs when HRT is set at $36 \mathrm{~h}$. The supernatant COD concentrations during the other four HRT stages were much higher than those recorded in the 36-h stage (Fig. 3b). The membrane's COD removal rate was also lowest $(25.84 \pm 1.68 \%)$ when HRT equalled $36 \mathrm{~h}$ (Fig. 3a). However, the situation changed for increased supernatant COD and membrane removal for the other four stages of HRT. Serious membrane fouling was observed when HRT equalled 72 or $24 \mathrm{~h}$, but supernatant COD and membrane
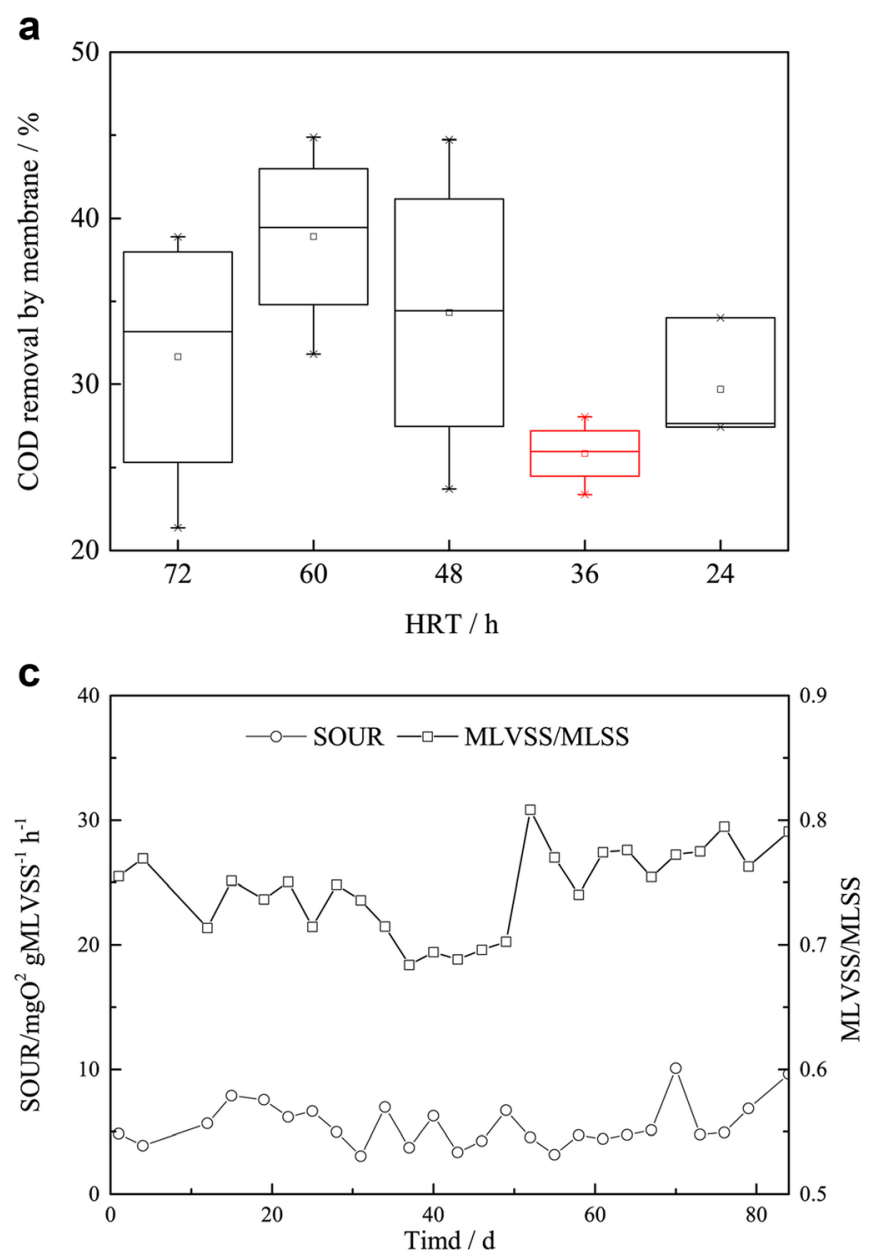

removal during these stages were not higher than during the stages of HRT at 60 and $48 \mathrm{~h}$ (Fig. 3a, b). COD membrane removal results suggest that membrane fouling trends can benefit from low supernatant COD $\left(377.75 \pm 21.68 \mathrm{mg} \mathrm{L}^{-1}\right)$ and a low removal rate $(25.84 \pm 1.68 \%)$ when HRT is at $36 \mathrm{~h}$, but the correlation was not significant at higher supernatant COD and membrane removal rates. Compared to the CAS system, effluent COD calculated in the MBR system decreased from $709.93 \pm 62.75$ to $280 \pm 17.32 \mathrm{mg} \mathrm{L}^{-1}$ (Table S1). The improved COD removal rate was much higher than the common membrane removal rate of $60 \sim 80 \%$, which implies that the removal of recalcitrant organics was enhanced by both the membrane and biomass through bioabsorption and biodegradation due to the increased presence of biomass and low food to microorganism $(\mathrm{F} / \mathrm{M})$ rates caused by prolonged SRT (>70 days) (Hai et al. 2010; Estrada-Arriaga and Mijaylova 2011; Raj et al. 2013).

Generally, MLSS concentrations will raise when HRT is decreased (Mutamim et al. 2012). However, in this study, MLSS increased from $4.47 \pm 0.82$ to $4.95 \pm 0.77 \mathrm{~g} \mathrm{~L}^{-1}$ when HRT was decreased from 72 to $24 \mathrm{~h}$. Considering that SRT> 70 days in this study, the MLSS was unusually lower than that

b

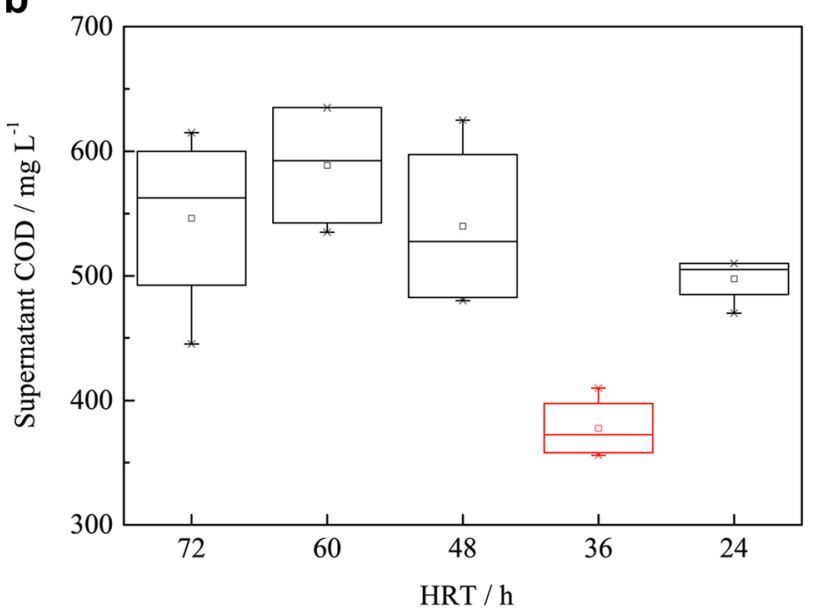

d

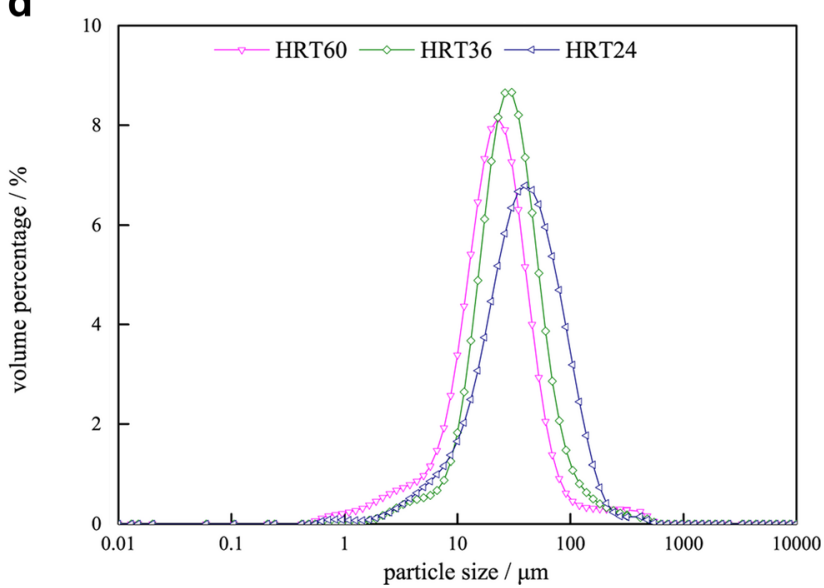

Fig. 3 Effects of different HRTs on mixed liquor (a COD removed by membrane, $\mathbf{b}$ supernatant COD, $\mathbf{c}$ biomass activity, and $\mathbf{d}$ particle size distribution) 
in the MBR system used to treat municipal wastewater (Meng et al. 2007). The same low MLSS concentration was observed at the pharmaceutical wastewater treatment station located at the Wuxi 2nd Pharmaceutical Factory. The station was operated at a volume loading rate (VLR) of $0.18-$ $1.3 \mathrm{~kg} \mathrm{COD} \mathrm{m}^{-3}$ day $^{-1}$, and dissolved oxygen (DO) was measured at approximately $3 \mathrm{mg} \mathrm{L}^{-1}$, which fell within the typical range for the CAS process. Given that the limited organic loading rate $(\mathrm{F} / \mathrm{M})$ and sludge discharged might inhibit MLSS increases, the organic loading rate was increased gradually and maintained sufficient DO and ALK levels (Table 1). However, compared with the 72-h measurements, MLSS dropped when the OLR doubled at $48 \mathrm{~h}$. When HRT decreased, MLSS exhibited limited growth, which varied largely from the linear growth measured in a municipal MBR system (Tay et al. 2003). The possible reasons for this quite low MLSS in the treatment of pharmaceutical wastewater are thought to be the low $\mathrm{F} / \mathrm{M}$ rate and endogenous decay under prolonged SRT (Hai et al. 2010).

As sludge growth was inhibited, another concern raised was sludge activity. The results of the MLVSS/MLSS ratio and SOUR data are shown in Fig. 3c. The MLVSS/MLSS ratio was $0.76 \pm 0.47$. The floc size distribution increased with decreasing HRT (Fig. 3d). According to the changes in SOUR and MLSS values during HRT optimization in this study, pharmaceutical wastewater seemed to inhibit MLSS growth but did not limit sludge activity in the SOUR.

\section{Factor analysis of membrane fouling}

Figure 4 shows the results of the principal components' (PCs) loading rates. Two PCs were extracted at loading values of 53.2 and $9.6 \%$, respectively. PC 1 was not only positively correlated to the biomass characteristics EPS and EPS $S_{c}$ and operating conditions OLR and MLVSS but was also negatively correlated to the biomass characteristics specific viscosity, CST, $\mathrm{TOC}_{\mathrm{m}}$, and SMP, and the operating condition $\mathrm{TOC}_{\mathrm{e}}$. The

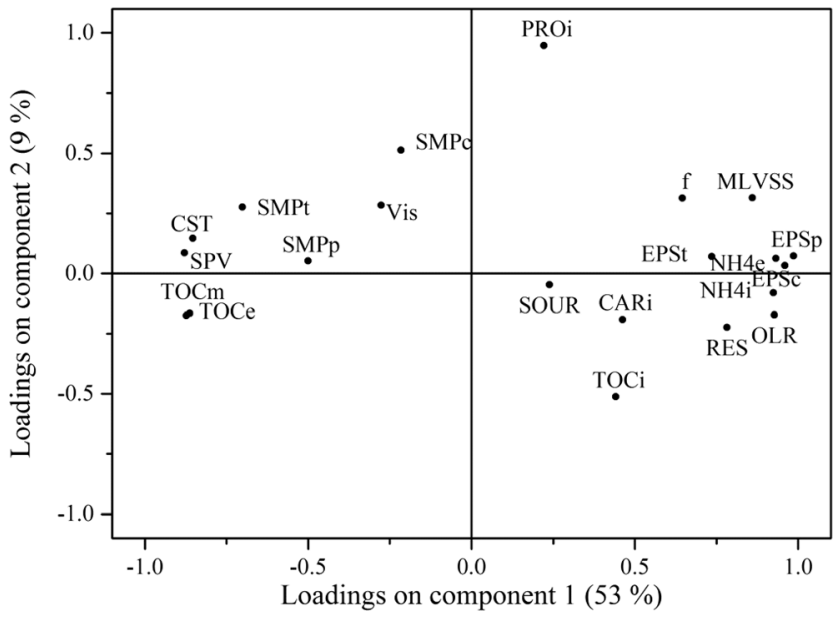

Fig. 4 Principal component analysis loading plot of PC 1 and PC 2 analysis identified $\mathrm{EPS}_{\mathrm{p}}$ and $\mathrm{EPS}_{\mathrm{c}}$ as major foulants in the MBR treatment of pharmaceutical wastewater. Membrane resistance was clustered with EPSc and OLR. PC 2 was positively correlated with protein in feed wastewater and negatively correlated with TOC in feed wastewater. Influent proteins played a critical role in PC 2 and may be linked to the production of antibiotics. In a summary, biomass characteristics, operational conditions, and feed characteristics were ranked in order according to their contributions to fouling trends in the MBR treatment of pharmaceutical wastewater.

Decreasing both EPS and SMP mitigates fouling rates in municipal MBR, which means that fouling rates are positively correlated with EPS and SMP (Chae et al. 2006; Trussell et al. 2006). Increased bound EPS leads to increasing membrane resistance and fouling in municipal MBR systems (Chae et al. 2006; Lesjean et al. 2005). These results were similar to those found in the present investigation. However, the effects of SMP on fouling were reversed in pharmaceutical wastewater. PCA results were shown to negatively correlate in this investigation (Fig. 4), and fouling (Fig. 1a) and bSMP (Fig. 2c) revealed opposite trends. Another notable difference is that influent proteins were an important component of PC 2. Additional investigation is needed to identify the mechanism behind these opposite trends.

\section{Conclusions}

(a) HRT was a significant operating parameter that affected membrane fouling and performance in a pharmaceutical MBR system. When HRT was decreased from 72 to $36 \mathrm{~h}$, irremovable fouling was maintained, and a further decrease to $24 \mathrm{~h}$ of HRT resulted in an increase of the irremovable fouling.

(b) Membrane foulants mainly contained proteins and carbohydrates; they were composed of bSMP, bEPS, and EfOM. Initial foulants were dominated by the bSMP in the 72-h HRT stage, and both bSMP and bEPS were major foulants when HRT equalled 60,48 , and $36 \mathrm{~h}$; the final fouling was dominated by bEPS. Decreasing HRT resulted in decreasing bSMP and EfOM, as well as increasing bEPS. This was related to the organic matter removal pathways via biodegradation or membrane retention.

(c) Statistic analyses have shown that $\mathrm{bEPS}_{\mathrm{p}}$ and $\mathrm{bEPS}_{\mathrm{c}}$ were significantly related to the membrane fouling rate. Other critical categories affecting membrane fouling were ranked in order as biomass characteristics, operational conditions, and feed characteristics.

$A L K$ alkalinity, $b E P S$ bound EPS, $b S M P$ bound SMP, $C A R$ carbohydrate, $C A S$ conventional activated sludge, $C S T$ capillary suction time, $C I P$ cleaning in place, $D O$ dissolved oxygen, EPS extracellular polymeric substance, $f$ MLVSS/MLSS, $F / M$ food to microorganism, MLVSS mixed liquor volatile 
suspended solid, $N F$ nanofiltration, $P R O$ protein, $R E S$ membrane resistance, $S E C$ size exclusion chromatography, SOUR specific oxygen uptake rate, $S P V$ specific viscosity of mixed liquor, $S M P$ soluble microbial product, $S R T$ solid retention time, TOC total organic carbon, Vis viscosity of mixed liquor, $i$ influent, $m$ mixed liquor of membrane bioreactor, $e$ effluent, $p$ protein, $c$ carbohydrate, and $t$ sum of related proteins and carbohydrates.

Acknowledgments Financial support from the Major Science and Technology Program for Water Pollution Control and Treatment of China (Nos. 2012ZX07203-002 and 2015ZX07203-005) is highly appreciated, as is support from the National High-Technology Research and Development Program ("863" Program) of China (No. 2009AA063901).

Author contributions Yutao Chen contributes equally with Dawei Yu. All authors contributed to the writing of this manuscript and have approved the final version of this manuscript.

\section{Compliance with ethical standards}

Conflict of interest The authors declare that they have no conflict of interest.

\section{References}

Berendonk TU et al (2015) Tackling antibiotic resistance: the environmental framework. Nat Rev Microbiol 13:310-317. doi:10.1038/ nrmicro3439

Chae SR, Ahn YT, Kang ST, Shin HS (2006) Mitigated membrane fouling in a vertical submerged membrane bioreactor (VSMBR). J Membr Sci 280:572-581. doi:10.1016/j.memsci.2006.02.015

Chang IS, Lee CH (1998) Membrane filtration characteristics in membrane-coupled activated sludge system - the effect of physiological states of activated sludge on membrane fouling. Desalination 120:221-233. doi:10.1016/S0011-9164(98)00220-3

Cheng YT (2012) Treatment and reclamation of antibiotic wastewater by combined membrane bioreactor and nanofiltration. Master thesis, Research Center for Eco-Environmental Sciences, Chinese Academy of Sciences

Cheng YT, Wei YS, Wang JX, Su YF, Li MY (2012) Comparison of membrane module performance in flat-sheet membrane bioreactor for treating spiramycin wastewater. China Water Wastewater 28:2024 (in Chinese)

Croue JP, Benedetti MF, Violleau D, Leenheer JA (2003) Characterization and copper binding of humic and nonhumic organic matter isolated from the South Platte River: evidence for the presence of nitrogenous binding site. Environ Sci Technol 37:328336. doi:10.1021/es020676p

DuBois M, Gilles KA, Hamilton JK, Rebers PA, Smith F (1956) Colorimetric method for determination of sugars and related substances. Anal Chem 28:350-356. doi:10.1021/ac60111a017

Estrada-Arriaga EB, Mijaylova PN (2011) Influence of operational parameters (sludge retention time and hydraulic residence time) on the removal of estrogens by membrane bioreactor. Environ Sci Pollut Res 18:1121-1128. doi:10.1007/s11356-011-0461-0

Hai FI, Yamamoto K, Nakajima F, Fukushi K (2010) Recalcitrant industrial wastewater treatment by membrane bioreactor (MBR). In: Gorley S (ed) Handbook of membrane research: properties, performance and applications. Nova Science Publishers, New York, pp 67-104. doi:10.1002/chin.201133280

Janga N, Ren X, Kim G, Ahn C, Cho J, Kim IS (2007) Characteristics of soluble microbial products and extracellular polymeric substances in the membrane bioreactor for water reuse. Desalination 202:90-98. doi:10.1016/j.desal.2005.12.043

Jubany I, Baeza JA, Carrera J, Lafuente J (2005) Respirometric calibration and validation of a biological nitrite oxidation model including biomass growth and substrate inhibition. Water Res 39:4574-4584. doi:10.1016/j.watres.2005.08.019

Lesjean B, Rosenberger S, Laabs C, Jekel M, Gnirss R, Amy G (2005) Correlation between membrane fouling and soluble/colloidal organic substances in membrane bioreactors for municipal wastewater treatment. Water Sci Technol 51:1-8

Lin HJ, Gao WJ, Meng FG, Liao BQ, Leung KT, Zhao LH, Chen JR, Hong HC (2012) Membrane bioreactors for industrial wastewater treatment: a critical review. Crit Rev Environ Sci Technol 42:677740

Lowry OH, Rosebrough NJ, Farr AL, Randall RJ (1951) Protein measurement with the folin phenol reagent. J Biol Chem 193:265-275

Malamis S, Andreadakis A (2009) Fractionation of proteins and carbohydrates of extracellular polymeric substances in a membrane bioreactor system. Bioresour Technol 100:3350-3357. doi:10.1016/j. biortech.2009.01.053

Meng FG, Shi BQ, Yang FL, Zhang HM (2007) Effect of hydraulic retention time on membrane fouling and biomass characteristics in submerged membrane bioreactors. Bioprocess Biosyst Eng 30:359 367. doi:10.1007/s00449-007-0132-1

Meng FG, Chae SR, Drews A, Kraume M, Shin HS, Yang FL (2009) Recent advances in membrane bioreactors (MBRs): membrane fouling and membrane material. Water Res 43:1489-1512. doi:10.1016/ j.watres.2008.12.044

Ministry of Environmental Protection of the People's Republic of China (2009) Pharmaceutical industrial pollution control technology and policy. http://www.mep.gov.cn/gkml/hbb/bgth/ 200911/ W020091109526715077565.pdf

Mutamim NSA, Noor ZZ, Hassan MAA, Olsson G (2012) Application of membrane bioreactor technology in treating high strength industrial wastewater: a performance review. Desalination 305:1-11. doi:10. 1016/j.desal.2012.07.033

Naessens W, Maere T, Nopens I (2012) Critical review of membrane bioreactor models - part 1: biokinetic and filtration models. Bioresour Technol 122:95-106. doi:10.1016/j.biortech.2012.05.070

Nagaoka H, Yamanishi S, Miya A (1998) Modeling of biofouling by extracellular polymers in a membrane separation activated sludge system. Water Sci Technol 38:497-504. doi:10.1016/S02731223(98)00550-2

National Bureau of Statistic China (2014) Industrial wastewater discharge and treatment. National Bureau of Statistic China, Beijing http:// www.stats.gov.cn/ztjc/ztsj/hjtjzl/2013/201412/ t20141216 654131. $\mathrm{html}$

Ng HY, Tan TW, Ong SL (2006) Membrane fouling of submerged membrane bioreactors: impact of mean cell residence time and the contributing factors. Environ Sci Technol 40:2706-2713. doi:10.1021/es0516155

Pendashteh AR, Fakhru'l-Razi A, Madaeni SS, Abdullah LC, Abidin ZZ, Biak DRA (2011) Membrane foulants characterization in a membrane bioreactor (MBR) treating hypersaline oily wastewater. Chem Eng J 168:140-150. doi:10.1016/j.cej.2010.12.053

Raj SE, Banu JR, Kaliappan S, Yeom I-T, Adish Kumar S (2013) Effects of side-stream, low temperature phosphorus recovery on the performance of anaerobic/anoxic/oxic systems integrated with sludge pretreatment. Bioresour Technol 140:376-384. doi:10.1016/j.biortech. 2013.04.061

Saha NK, Balakrishnan M, Ulbricht M (2007) Sugarcane juice ultrafiltration: FTIR and SEM analysis of polysaccharide fouling. J Membr Sci 306:287-297. doi:10.1016/j.memsci.2007.09.006 
Shariati SRP, Bonakdarpour B, Zare N, Ashtiani FZ (2011) The effect of hydraulic retention time on the performance and fouling characteristics of membrane sequencing batch reactors used for the treatment of synthetic petroleum refinery wastewater. Bioresour Technol 102: 7692-7699. doi:10.1016/j.biortech.2011.05.065

Shon HK, Vigneswaran S, Snyder SA (2006) Effluent organic matter (EfOM) in wastewater: constituents, effects, and treatment. Crit Rev Env Sci Tec 36:327-374. doi:10.1080/10643380600580011

Sipma J, Osuna B, Collado N, Monclus H, Ferrero G, Comas J, Rodriguez-Roda I (2010) Comparison of removal of pharmaceuticals in MBR and activated sludge systems. Desalination 250:653659. doi:10.1016/j.desal.2009.06.073

State Council of China (2015) The action plan for water pollution prevention and control. http://www.gov.cn/zhengce/content/2015-04/ 16/content 9613.htm

Sun DD, Hay CT, Khor SL (2006) Effects of hydraulic retention time on behavior of start-up submerged membrane bioreactor with prolonged sludge retention time. Desalination 195:209-225. doi: 10.1016/j.desal.2005.12.002

Sundararaman S, Saravanane R (2010) Effect of loading rate and HRT on the removal of cephalosporin and their intermediates during the operation of a membrane bioreactor treating pharmaceutical wastewater. Water Sci Technol 61:1907-1914. doi:10.2166/wst.2010.881

Tay JH, Zeng JL, Sun DD (2003) Effects of hydraulic retention time on system performance of a submerged membrane bioreactor. Sep Sci Technol 38:851-868. doi:10.1081/Ss-120017630

Trussell RS, Merlo RP, Hermanowicz SW, Jenkins D (2006) The effect of organic loading on process performance and membrane fouling in a submerged membrane bioreactor treating municipal wastewater. Water Res 40:2675-2683. doi:10.1016/j.watres.2006.04.020
Viero AF, Sant'Anna GL (2008) Is hydraulic retention time an essential parameter for MBR performance? J Hazard Mater 150:185-186. doi:10.1016/j.jhazmat.2007.09.090

Wang JX, Wei YS, Cheng YT (2014a) Advanced treatment of antibiotic wastewater by nanofiltration: membrane selection and operation optimization. Desalin Water Treat 52:7575-7585. doi:10.1080/ 19443994.2013.833868

Wang JX, Wei YS, Li K, Cheng YT, Li MY, Xu J (2014b) Fate of organic pollutants in a pilot-scale membrane bioreactor-nanofiltration membrane system at high water yield in antibiotic wastewater treatment. Water Sci Technol 69:876-881. doi:10.2166/wst.2013.789

Wang JX, Li K, Wei YS, Cheng YT, Wei D, Li MY (2015) Performance and fate of organics in a pilot MBR-NF for treating antibiotic production wastewater with recycling NF concentrate. Chemosphere 121:92-100. doi:10.1016/j.chemosphere.2014.11.034

Water and Wastewater Monitoring Method Editorial Committee (2002) Water and wastewater monitoring method. China Environmental Science Press, Beijing

Xing ZP, Sun DZ (2009) Treatment of antibiotic fermentation wastewater by combined polyferric sulfate coagulation, Fenton and sedimentation process. J Hazard Mater 168:1264-1268. doi:10.1016/j. jhazmat.2009.03.008

Zhou Y, Xu ZL, Munib S, Chen GE, Lu Q (2009) Sustainable membrane operation design for the treatment of the synthetic coke wastewater in SMBR. Water Sci Technol 60:2115-2124. doi:10.2166/wst.2009. 540

Zuriaga-Agustí E, Alventosa-deLara E, Barredo-Damas S, AlcainaMiranda MI, Iborra-Clar MI, Mendoza-Roca JA (2014) Performance of ceramic ultrafiltration membranes and fouling behavior of a dye-polysaccharide binary system. Water Res 54:199210. doi:10.1016/j.watres.2014.01.064 